\title{
Evaluating Sustainable Use and Management of Winery Solid Wastes through Composting
}

\author{
A.R. Mulidzi \\ Soil and Water Science Division, ARC Infruitec-Nietvoorbij, Private Bag X 5026, Stellenbosch 7599, South Africa
}

Submitted for publication: May 2021

Accepted for publication: September 2021

Key words: Bentonite lees, Compost heap, Grapevine, Winery solid waste

\begin{abstract}
Most solid waste produced by South African wineries during wine making processes includes wine filter wastes derived from perlite and Diatomaceous earth. Wine filter wastes together with grapevine pruning canes, berry skins, seeds and stalks can be used to make compost as a waste minimization and management strategy for the wine industry. The objective of the study was to investigate the feasibility of using winery solid waste and grape products on composting. Wine filter wastes together with grapevine pruning canes and berry skins, seeds and stalks were successfully used to make compost of good quality. Compost piles that had between $\mathbf{4 0 \%}$ to $\mathbf{5 0 \%}$ of wine filter wastes resulted in successful composting. Turning of compost heaps increased temperatures, which was a positive factor during composting. Furthermore, some compost parameters are likely to change from season to season as composting weather conditions, quantities and probably also chemical composition of wine filter wastes generated seasonally may vary.
\end{abstract}

\section{INTRODUCTION}

Increased wine production has resulted in wineries generating large volumes of wastes and this puts pressure on natural resources (Mulidzi et al., 2016). Most solid waste produced by South African wineries during wine making processes include filter wastes and clarifying that were derived from perlite and Diatomaceous earth (Mulidzi et al., 2018). This waste cannot be disposed in the environment without following legislation as the leachate may contain residues that are harmful (Mulidzi, 2021). There are wineries that still dispose of waste on their own land (Zingelwa-Masekwana, 2012). In addition, some wineries dump solid wastes in rented dumping sites and municipal landfills (Masowa et al., 2015).

Currently, there are increasing limits about the use of landfills and global environmental related pressures for industries to manage waste in a more sustainable way (Mulidzi, 2001). In a study done at different South African wineries, it was observed that most of the difficult waste to treat during wine making processes was generated through the use of filter powders such as Diatomaceous earth and perlite (Zingelwa-Masekwana, 2012). Most wineries prefer that bentonite lees and used filtration material be sent to commercial recycling companies for the recovery of alcohol and tartaric acid to prevent the leaching of the alcohol and acid, which can pollute the environment (Theron, 2013). Wineries are obliged to comply with government legislations regarding waste disposal and management (Mulidzi et al.,
2015). Lack of proper management of solid wastes could lead to serious environmental pollution for the wine industry hence alternative waste minimization and management strategies need to be investigated (Mulidzi, et al., 2016). Recycling of wastes through composting is generally used as a management strategy of organic waste (Arvanitoyannis et al., 2006). Recycling of waste is regarded as most effective waste treatment adopted worldwide (Mtimkulu, et al., 2016). Bertran et al., (2004), define composting as decomposition of organic wastes and biological control under conditions that allow development of thermophilic temperatures. The process is used worldwide as a treatment for solid organic waste (Masowa et al., 2018). After composting, the final product normally has a smaller volume and mass than the initial material and may have a high agronomic value (Bonthuys, 2016).

The objectives of the study were three-fold, namely to (i) determine the effects of using varying amounts of wine filter waste materials, together with other grape and vineyard materials on compost characteristics, (ii) determine the effects of turning and not turning compost heaps on compost characteristics and (iii) determine the effects of lining and not lining compost heaps on compost characteristics. 


\section{MATERIALS AND METHODS}

Treatments

The study was conducted at the Agricultural Research Council Nietvoorbij farm in Stellenbosch, South Africa over three consecutive vintage years, i.e. 2012/13, 2013/14 and $2014 / 15$. Thirty six compost heaps $\left(\approx 3 \mathrm{~m}^{3}\right)$ were laid out following a randomised block design. Details of the treatments are described in Table 1 as follows: T0 where no winery filter waste $\{0 \%$ Winery Filter Waste (WFW) $\}=[0 \%$ Winery Filter Waste perlite derived (FWp)+ Diatomaceous earth derived (de) $+67 \%$ Pruning Canes (PC) $+8 \%$ Berry stalks (BS) $+25 \%$ Berry skins and seeds (BSS)]; $\mathrm{T} 1(\approx 40 \% \mathrm{WFW})=[32 \% \mathrm{WFWp}+8 \% \mathrm{WFWde}+40 \% \mathrm{PC}+$ $5 \% \mathrm{BS}+15 \% \mathrm{BSS})$ and $\mathrm{T} 2(\approx 50 \% \mathrm{WFW})=[42 \% \mathrm{WFWp}+$ $8 \%$ WFWde $+40 \%$ PC, 5\% BS $+5 \%$ BSS $)]$. The subplot factors were: (a) turning and (b) lining treatments of the compost heaps. The turning treatment was divided into (i) No-turn, which involved compost heaps that were not turned (ii) Turn, which involved compost heaps that were turned once a week. The lining treatment was divided into (i) Nolining, which involved compost heaps that were laid out on bare hardened soil surfaces and (ii) Lining, which involved compost heaps that were laid out on surfaces lined with a $1 \mathrm{~mm}$ dam plastic liner. Temperatures were measured on a weekly basis using a $1 \mathrm{~m}$ long temperature probe during different composting stages. Compost heaps were harvested and sampled after approximately 5 (2012/13), exactly 5 $(2013 / 14)$ and 4 months $(2014 / 15)$ and thereafter analysed for selected chemical parameters such as $(\mathrm{pH}$, Potassium, Sodium, Phosphorus and others). Data was analysed separately per season and combined, making it possible to observe the effects of using WFW from different seasons on the composting process and the composition of the final composts.

\section{RESULTS}

Effects of using varying amounts of winery wastes on compost characteristics

\section{Temperatures}

Temperatures seemed to decrease with composting stages and $\mathrm{T} 1$ attained mean temperatures that were significantly higher by $4^{\circ} \mathrm{C}$ and $2^{\circ} \mathrm{C}$ during composting stages 60 and 120 days, respectively than those of T2 (Table 2). During the rest of the stages, $\mathrm{T} 1$ and $\mathrm{T} 2$ exhibited similar temperatures and both reached their highest temperatures during the initial composting stage (Table 2). Therefore, T1 reached higher mean temperatures than $\mathrm{T} 2$, in the beginning $\left(29^{\circ} \mathrm{C}\right.$ vs. $\left.25^{\circ} \mathrm{C}\right)$ and towards the end stages $\left(24^{\circ} \mathrm{C}\right.$ vs. $\left.22^{\circ} \mathrm{C}\right)$ of composting. Furthermore, with all three years of temperature data combined, T1 and T2 attained average temperatures of $24.90^{\circ} \mathrm{C}$ and $23.93^{\circ} \mathrm{C}$, respectively during an approximately 135-day composting period (data not shown).

\section{TABLE 1}

Percentage (\%) allocations of winery and vineyard waste materials making up various treatments for the 2012/13 to 2014/15 compost production periods.

\begin{tabular}{|c|c|c|c|c|c|}
\hline \multirow[t]{2}{*}{$\begin{array}{l}\text { Main treatments } \\
\text { (\% Wine filter wastes) }\end{array}$} & \multicolumn{2}{|c|}{ Wine filter wastes (WFW) \% } & \multirow[t]{2}{*}{$\begin{array}{c}\text { Pruning } \\
\text { canes }(\%)\end{array}$} & \multirow[t]{2}{*}{$\begin{array}{c}\text { Berry } \\
\text { stalks (\%) }\end{array}$} & \multirow[t]{2}{*}{$\begin{array}{c}\text { Berry skins } \\
\text { and seeds (\%) }\end{array}$} \\
\hline & Perlite-derived ( $\mathrm{p}$ ) & $\begin{array}{l}\text { Diatomaceous earth- } \\
\text { derived (de)** }\end{array}$ & & & \\
\hline T0 (0\%WFWp*+de) & 0 & 0 & 67 & 8 & 25 \\
\hline $\mathrm{T} 1(\approx 40 \% \mathrm{WFWp}+\mathrm{de})$ & 32 & 8 & 40 & 5 & 15 \\
\hline $\mathrm{T} 2(\approx 50 \% \mathrm{WFWp}+\mathrm{de})$ & 42 & 8 & 40 & 5 & 5 \\
\hline
\end{tabular}

*Winery filter waste perlite derived (WFWp)

**Diatomaceous earth derived (de)

TABLE 2

Mean temperatures of various winery solid waste composts during different composting stages of the 2012/13 to 2014/15 compost production periods.

\begin{tabular}{cllc}
\hline Composting stages & & Temperature $\left({ }^{\circ} \mathrm{C}\right)$ of main-treatments & \\
\hline (days) & $\mathrm{T}^{(1)}$ & $\mathrm{T} 1^{(1)}$ & $\mathrm{T} 2^{(1)}$ \\
\hline 60 & $21.74 \mathrm{hij}^{(2)}$ & $29.13 \mathrm{a}$ & $25.30 \mathrm{~cd}$ \\
75 & $21.33 \mathrm{j}$ & $25.74 \mathrm{bc}$ & $25.88 \mathrm{~b}$ \\
90 & $22.10 \mathrm{hi}$ & $24.72 \mathrm{ef}$ & $24.82 \mathrm{de}$ \\
105 & $21.27 \mathrm{j}$ & $24.25 \mathrm{fg}$ & $23.91 \mathrm{~g}$ \\
120 & $21.50 \mathrm{j}$ & $23.88 \mathrm{~g}$ & $22.17 \mathrm{~h}$ \\
135 & $20.45 \mathrm{k}$ & $21.65 \mathrm{ij}$ & $21.51 \mathrm{j}$ \\
\hline
\end{tabular}

(1) Refer to Table 1

${ }^{(2)}$ Different letters within the same rows and columns denote significant differences $(\mathrm{P}=0.05)$ 


\section{Chemical and physical parameters}

Chemical and physical parameters of final winery solid waste composts produced over three production seasons (2012/13 to 2014/15) and commercial composts (CC2 \& CC3) are indicated in Table 3.

$p H$ : Overall, $\mathrm{pH}$ values increased significantly with the use of wine filter wastes, shifting them from acidic (T0) to basic (T1 and T2) while T2 obtained higher values than T1. The $\mathrm{pH}$ values of both $\mathrm{T} 1$ and $\mathrm{T} 2$ were comparable to those of CC2 (Table 3).

Macro-elements: Nitrogen, $\mathrm{P}$ and $\mathrm{Na}$ contents increased significantly with the use of wine filter wastes and were similar in both T1 and T2 (Table 3). Furthermore, K contents increased significantly with the use of wine filter wastes and $\mathrm{T} 2$ had higher levels than T1. In contrast, $\mathrm{C}$ contents, $\mathrm{C} / \mathrm{N}$ ratios, $\mathrm{Ca}$ as well as $\mathrm{Mg}$ contents decreased significantly with the use of wine filter wastes (Table 3 ). The $\mathrm{C}$ contents, $\mathrm{C} / \mathrm{N}$ ratios were similar for both $\mathrm{T} 1$ and $\mathrm{T} 2$, regardless of the differences in wine filter wastes. However, T2 was found with lower $\mathrm{Ca}$ and $\mathrm{Mg}$ contents than $\mathrm{T} 1$ (Table 3). Nitrogen, $\mathrm{K}, \mathrm{Ca}$ and $\mathrm{Mg}$ contents as well as Na concentrations of $\mathrm{T} 1$ and T2 were above those of both commercial composts (Table 3 ). The P levels of both $\mathrm{T} 1$ and $\mathrm{T} 2$ were below and above those of $\mathrm{CC} 2$ and $\mathrm{CC} 3$, respectively. However, $\mathrm{C}$ contents of both T1 and T2 were comparable to those of both commercial composts.

Micro-elements: Concentrations of $\mathrm{B}$ and $\mathrm{Fe}$ increased significantly with the use of wine filter wastes (Table 3). Concentrations of $\mathrm{B}$ were similar in both $\mathrm{T} 1$ and $\mathrm{T} 2$, while those of Fe were higher for T2 than T1. Concentrations of $\mathrm{Cu}, \mathrm{Mn}$ and $\mathrm{Zn}$ decreased significantly with the use of wine filter wastes (Table 3). Concentrations of $\mathrm{Cu}$ and $\mathrm{Mn}$ were similar for both $\mathrm{T} 1$ and $\mathrm{T} 2$, while those of $\mathrm{Zn}$ were lower for $\mathrm{T} 2$ than $\mathrm{T} 1$. Concentrations of $\mathrm{B}$ and $\mathrm{Fe}$ for $\mathrm{T} 1$ and $\mathrm{T} 2$ were above those of commercial composts, but, those of $\mathrm{Cu}$ for $\mathrm{T} 1$ and $\mathrm{T} 2$, could be considered comparable to those $\mathrm{CC} 2$, while those of $\mathrm{Mn}$ and $\mathrm{Zn}$ to those of CC3.

Physical parameters: Moisture contents increased significantly with the use of wine filter wastes where T1 was used, while decreasing with regards to T2 (Table 3). Therefore, overall $\mathrm{T} 2$ contained a lower moisture content than $\mathrm{T} 1$. Density values and ash contents increased significantly with the use of wine filter wastes, but T1 was found with higher and lower, density values and ash contents, respectively than T2. Overall, the three compost production seasons, regardless of the differences in the amounts of wine filter wastes used, T1

TABLE 3

Chemical and physical parameters of winery solid waste composts produced over three seasons (2012/13-2014/15) and commercial composts bought for comparison.

\begin{tabular}{|c|c|c|c|c|c|}
\hline \multirow[t]{2}{*}{ Characteristics } & \multicolumn{3}{|c|}{ Main treatments ${ }^{(1)}$} & \multicolumn{2}{|c|}{ Commercial composts } \\
\hline & T0 & $\mathrm{T} 1$ & $\mathrm{~T} 2$ & $\mathrm{CC} 2$ & CC3 \\
\hline $\mathrm{pH}$ & $6,52 \mathrm{c}^{(2)}$ & $8,75 b$ & $9,27 \mathrm{a}$ & 8.2 & 5.7 \\
\hline Resistance(Ohm) & $185 \mathrm{a}$ & $67 b$ & $62 c$ & - & - \\
\hline $\mathrm{C}(\%)$ & $21,25 a$ & $16,33 b$ & $16,07 b$ & 19.40 & 19.92 \\
\hline $\mathrm{N}(\%)$ & $1,86 b$ & $2,18 \mathrm{a}$ & $2,11 \mathrm{a}$ & 1.33 & 0.73 \\
\hline $\mathrm{C} / \mathrm{N}$ & $11 \mathrm{a}$ & $8 b$ & $8 \mathrm{~b}$ & 15 & 27 \\
\hline $\mathrm{P}(\%)$ & $0,11 b$ & $0,26 \mathrm{a}$ & $0,26 \mathrm{a}$ & 0.53 & 0.12 \\
\hline $\mathrm{K}(\%)$ & $0,91 \mathrm{c}$ & $3,50 \mathrm{~b}$ & $4,25 \mathrm{a}$ & 0.0034 & 0.0009 \\
\hline $\mathrm{Ca}(\%)$ & $0,86 a$ & $0,57 \mathrm{~b}$ & $0,50 \mathrm{c}$ & 0.0037 & 0.0023 \\
\hline $\operatorname{Mg}(\%)$ & $0,23 \mathrm{a}$ & $0,11 b$ & $0,09 \mathrm{c}$ & 0.0017 & 0.0006 \\
\hline $\mathrm{Na}(\mathrm{mg} / \mathrm{kg})$ & $935 b$ & $3659 a$ & $3757 \mathrm{a}$ & 10.3 & 2.48 \\
\hline $\mathrm{B}(\mathrm{mg} / \mathrm{kg})$ & $31,15 b$ & $45,83 a$ & $47,17 \mathrm{a}$ & 10.96 & 3.95 \\
\hline $\mathrm{Fe}(\mathrm{mg} / \mathrm{kg})$ & $6241 \mathrm{c}$ & $7667 b$ & $8312 \mathrm{a}$ & 485 & 463 \\
\hline $\mathrm{Cu}(\mathrm{mg} / \mathrm{kg})$ & $21,59 a$ & $16,48 b$ & $16,83 b$ & 9.61 & 4.27 \\
\hline $\mathrm{Mn}(\mathrm{mg} / \mathrm{kg})$ & $52,59 a$ & $46,09 b$ & $44,95 b$ & 197.39 & 66.50 \\
\hline $\mathrm{Zn}(\mathrm{mg} / \mathrm{kg})$ & $48,79 a$ & $32,19 b$ & $27,71 \mathrm{c}$ & 145.67 & 34.27 \\
\hline Moisture(\%) & $63,78 b$ & $64,97 \mathrm{a}$ & $62,64 \mathrm{c}$ & - & - \\
\hline $\operatorname{Density}\left(\mathrm{kg} / \mathrm{m}^{3}\right)$ & $682 \mathrm{c}$ & $857 \mathrm{a}$ & $822 b$ & - & - \\
\hline $\operatorname{Ash}(\%)$ & $29,14 \mathrm{c}$ & $55,29 b$ & $59,08 \mathrm{a}$ & - & - \\
\hline
\end{tabular}

(1)Refer to Table 1

${ }^{(2)}$ Different letters within the same row denote significant differences during each stage $(\mathrm{P}=0.05, \mathrm{~N}=36)$ 
and $\mathrm{T} 2$ were found with similar $\mathrm{C}$ and $\mathrm{N}$ contents, $\mathrm{C}: \mathrm{N}$ ratios and $\mathrm{P}$ contents as well as $\mathrm{Na}, \mathrm{B}, \mathrm{Cu}$ and $\mathrm{Mn}$ concentrations. However, T2 was found with $\mathrm{pH}$ values, $\mathrm{K}$ contents, $\mathrm{Fe}$ concentrations as well as ash contents that were significantly higher than those of T1. T2 was found with resistance, Ca and $\mathrm{Mg}, \mathrm{Zn}$, moisture contents and density values that were lower than those of T1. Although, some chemical parameters of the wine filter waste composts were found in comparable levels to those of commercial composts, most were found in levels that exceeded those of commercial composts. Overall, the wine filter wastes compost produced could be characterised as follows: high $\mathrm{pH}$ and low resistance values, adequate $\mathrm{N}$ and $\mathrm{P}$, high $\mathrm{K}$ contents, excessively high $\mathrm{Na}$ and Fe concentrations and with adequate $\mathrm{B}$ concentrations that should be closely monitored if the compost is used in the field.

\section{Effects of turning and not turning wine filter waste compost heaps \\ Temperatures}

With all the three-year data combined, T1 (Turn) attained mean temperatures that were significantly higher by $5^{\circ} \mathrm{C}$ to $8^{\circ} \mathrm{C}$ than those of T1 (No-turn) in all identified composting stages (Table 4). T2 (Turn) reached temperatures that were significantly higher by $3^{\circ} \mathrm{C}$ to $5^{\circ} \mathrm{C}$ than those of T2 (No-turn) in all composting stages. Turning of heaps therefore resulted in increased temperatures in almost all the composting stages.

\section{Chemical parameters}

Turning of compost heaps resulted in significant increases in levels of $\mathrm{pH}, \mathrm{P}, \mathrm{K}, \mathrm{Fe}$ and $\mathrm{Mn}$ concentrations, however there were decreases in resistance values, $\mathrm{C}$ contents, N, C: N ratios, $\mathrm{Ca}$ and $\mathrm{Mg}$ contents, concentrations of $\mathrm{B}, \mathrm{Cu}$, and $\mathrm{Zn}$ (T1-Turn only), moisture contents as well as density values (data not shown). Therefore, overall, with the exception of $\mathrm{Na}$, all the chemical and physical parameters of one or both final wine filter waste composts were significantly affected by turning and not turning activities of compost heaps.
Effects of lining and not lining of compost heap surfaces Temperatures

Composting temperatures as affected by the use of a lining on compost heap surfaces during the various composting stages over the 2012/13-2014/15 period are indicated in Table 5. T1Lining attained temperatures that were significantly lower by approximately $1{ }^{\circ} \mathrm{C}$ than those of T1 No-lining during Stages 60 and 90. In contrast, during the rest of the stages T1Lining attained temperatures that were higher by $1{ }^{\circ} \mathrm{C}$ than those of T1 No-lining. T2-Lining attained temperatures that were higher by $1{ }^{\circ} \mathrm{C}$ than those of T2 No-lining during Stage 60. However, T2-Lining attained temperatures that were higher by approximately $1^{\circ} \mathrm{C}$ and $2^{\circ} \mathrm{C}$, during Stages 75 and 90, respectively. Therefore, overall 3 composting seasons, temperatures were found generally higher in lined compost heaps than unlined compost heaps during most composting stages and T1 was generally more sensitive to the use of a lining than $\mathrm{T} 2$.

\section{Chemical parameters}

Chemical and physical parameters of final winery solid waste composts from lined and not lined compost heap surfaces produced during the 2012/13-2014/15 period are indicated in Table 6. Overall, the use of a lining on composting surfaces resulted in increased $\mathrm{pH}$ levels, $\mathrm{C}$ and $\mathrm{N}$ contents, $\mathrm{C}: \mathrm{N}$ ratios, $\mathrm{P}, \mathrm{K}, \mathrm{Ca}$ and $\mathrm{Mg}$ contents, $\mathrm{Na}$ and $\mathrm{B}$ concentrations, moisture levels, and decreased $\mathrm{Fe}$ and $\mathrm{Cu}$ (T1-Lining only) concentrations and ash contents in final wine filter waste composts.

\section{Effects of seasons on wine filter waste composting process and characteristics of final compost \\ Temperature}

The highest mean temperatures for both $\mathrm{T} 1$ and $\mathrm{T} 2$ were measured during 2013/14, while the lowest in 2014/15 (data not shown). Overall, T1 attained the highest and the lowest mean temperatures during the 2013/14 and 2014/15 compost production periods, and was therefore more sensitive to seasonal changes than T2, as T2 was not affected significantly by seasonal changes (data not shown). Climatic conditions

\section{TABLE 4}

Temperatures of turned (Turn) and not turned (No-turn) winery solid waste compost heaps (sub-treatments) produced during various composting stages of the 2012/13 to 2014/15 period.

\begin{tabular}{|c|c|c|c|c|c|c|}
\hline \multirow[t]{3}{*}{ Composting stages } & \multicolumn{6}{|c|}{ Temperatures $\left({ }^{\circ} \mathrm{C}\right)$} \\
\hline & $\mathrm{TO}^{(1)}$ & T0 & $\mathrm{T} 1^{(1)}$ & $\mathrm{T} 1$ & $\mathrm{~T} 2^{(1)}$ & $\mathrm{T} 2$ \\
\hline & Turn & No-turn & Turn & No-turn & Turn & No-turn \\
\hline 60 & $23.27 \mathrm{ij}^{(2)}$ & $20.21 o p q$ & $32.85 \mathrm{a}$ & $25.42 \mathrm{f}$ & $26.02 \mathrm{ef}$ & $24.58 \mathrm{~g}$ \\
\hline 75 & $22.42 \mathrm{kl}$ & $20.23 \mathrm{opq}$ & $28.48 b$ & $23.01 \mathrm{jk}$ & $27.99 b c$ & 23.77hi \\
\hline 90 & $23.58 \mathrm{hij}$ & 20.620 & $27.38 \mathrm{~cd}$ & $22.061 \mathrm{~m}$ & $27.17 d$ & $22.50 \mathrm{kl}$ \\
\hline 105 & $22.94 \mathrm{jk}$ & $19.59 \mathrm{qrs}$ & $27.15 d$ & $21.35 n$ & $26.36 \mathrm{e}$ & $21.45 \mathrm{mn}$ \\
\hline 120 & $23.07 \mathrm{jk}$ & $19.93 p q$ & $27.30 \mathrm{~d}$ & 20.45 op & $24.25 \mathrm{gh}$ & $20.10 \mathrm{opq}$ \\
\hline 135 & $21.891 \mathrm{mn}$ & $19.01 \mathrm{~s}$ & $24.19 \mathrm{gh}$ & 19.11rs & $23.28 \mathrm{ij}$ & $19.73 \mathrm{qr}$ \\
\hline
\end{tabular}

${ }^{(1)}$ Refer to Table 1

${ }^{(2)}$ Different letters within the same rows and columns denote significant differences during all stages $(\mathrm{P}=0.05)$ 
TABLE 5

Temperatures of lined (Lining) and not lined (No-lining) winery solid waste compost during different composting stages of the 2012/13-2014/15 period.

\begin{tabular}{|c|c|c|c|c|c|c|}
\hline \multirow[t]{3}{*}{ Composting stages } & \multicolumn{6}{|c|}{ Temperatures $\left({ }^{\circ} \mathrm{C}\right)$} \\
\hline & $\mathrm{T}^{(1)}$ & T0 & $\mathrm{T} 1^{(1)}$ & T1 & $\mathrm{T} 2^{(1)}$ & $\mathrm{T} 2$ \\
\hline & -Lining & No-lining & -Lining & No-lining & -Lining & No-lining \\
\hline 60 & $22.21 \mathrm{kl}^{(2)}$ & $21.28 \mathrm{mnopq}$ & $28.73 b$ & $29.54 \mathrm{a}$ & $24.74 \mathrm{gh}$ & $25.86 \mathrm{~cd}$ \\
\hline 75 & 20.89nopq & $21.76 \mathrm{klmn}$ & $26.41 \mathrm{c}$ & $25.08 \mathrm{efg}$ & $26.29 c$ & $25.47 \mathrm{def}$ \\
\hline 90 & $22.39 \mathrm{k}$ & $21.81 \mathrm{klmn}$ & 24.32hi & $25.12 \mathrm{efg}$ & $25.74 \mathrm{cde}$ & $23.89 \mathrm{ij}$ \\
\hline 105 & $20.78 \mathrm{pqr}$ & $21.75 \mathrm{klmn}$ & $24.91 \mathrm{fgh}$ & $24.00 \mathrm{j}$ & $23.96 \mathrm{ij}$ & $23.85 \mathrm{ij}$ \\
\hline 120 & $21.551 \mathrm{mno}$ & 21.45 mnop & $24.48 \mathrm{ghi}$ & $23.27 \mathrm{j}$ & $21.96 \mathrm{klm}$ & $22.39 \mathrm{k}$ \\
\hline 135 & $20.31 \mathrm{r}$ & $20.59 \mathrm{rq}$ & $22.17 \mathrm{kl}$ & $21.13 \mathrm{nopq}$ & $21.70 \mathrm{klmn}$ & $21.32 \mathrm{mnop}$ \\
\hline
\end{tabular}

${ }^{(1)}$ Refer to Table 1

${ }^{(2)}$ Different letters within the same rows and columns denote significant differences during all stages $(\mathrm{P}=0.05)$

TABLE 6

Chemical and physical parameters of winery solid waste composts from lined (Lining) and not lined (No-lining) compost heap surfaces produced during 3 seasons (2012/13-2014/15).

\begin{tabular}{|c|c|c|c|c|c|c|}
\hline \multirow[t]{3}{*}{ Parameters } & \multicolumn{6}{|c|}{ Sub-treatments } \\
\hline & $\mathrm{T} 0^{(1)}$ & T0 & $\mathrm{T} 1^{(1)}$ & $\mathrm{T} 1$ & $\mathrm{~T} 2^{(1)}$ & \\
\hline & -Lining & No-lining & -Lining & No-lining & -Lining & No-lining \\
\hline $\mathrm{pH}$ & $6.54 \mathrm{~d}^{(2)}$ & $6.49 \mathrm{~d}$ & $8.98 b$ & $8.53 \mathrm{c}$ & $9.56 \mathrm{a}$ & $8.96 b$ \\
\hline Resistance(Ohm) & $201 b$ & $214 \mathrm{a}$ & $66 \mathrm{~cd}$ & $71 \mathrm{c}$ & $60 d$ & $66 \mathrm{~cd}$ \\
\hline$C(\%)$ & $23.50 \mathrm{a}$ & $19.01 b$ & $18.86 b$ & $13.80 \mathrm{c}$ & $17.74 b$ & $14.40 \mathrm{c}$ \\
\hline $\mathrm{N}(\%)$ & $2.02 \mathrm{~b}$ & $1.70 \mathrm{~d}$ & $2.42 \mathrm{a}$ & $1.94 \mathrm{bc}$ & $2.32 \mathrm{a}$ & $1.89 \mathrm{c}$ \\
\hline $\mathrm{C} / \mathrm{N}$ & $12 \mathrm{a}$ & $11 b$ & $8 \mathrm{c}$ & $7 d$ & $8 \mathrm{~cd}$ & $8 \mathrm{~cd}$ \\
\hline $\mathrm{P}(\%)$ & $0.12 \mathrm{c}$ & $0.11 \mathrm{~d}$ & $0.29 \mathrm{a}$ & $0.22 b$ & $0.31 \mathrm{a}$ & $0.22 b$ \\
\hline $\mathrm{K}(\%)$ & $0.99 \mathrm{e}$ & $0.83 \mathrm{e}$ & $4.54 b$ & $2.58 \mathrm{~d}$ & $5.46 \mathrm{a}$ & $3.05 \mathrm{c}$ \\
\hline $\mathrm{Ca}(\%)$ & $0.93 \mathrm{a}$ & $0.79 b$ & $0.62 \mathrm{c}$ & $0.51 \mathrm{~d}$ & $0.55 \mathrm{~d}$ & $0.45 \mathrm{e}$ \\
\hline $\operatorname{Mg}(\%)$ & $0.25 \mathrm{a}$ & $0.21 b$ & $0.13 \mathrm{c}$ & $0.09 \mathrm{~d}$ & $0.10 \mathrm{~d}$ & $0.08 \mathrm{e}$ \\
\hline $\mathrm{Na}(\mathrm{mg} / \mathrm{kg})$ & $992 d$ & $879 d$ & $4206 b$ & $3081 \mathrm{c}$ & $4372 \mathrm{a}$ & $3143 c$ \\
\hline $\mathrm{B}(\mathrm{mg} / \mathrm{kg})$ & $33.50 \mathrm{c}$ & $28.93 d$ & $51.02 \mathrm{a}$ & $40.34 b$ & $53.17 \mathrm{a}$ & $41.16 b$ \\
\hline $\mathrm{Fe}(\mathrm{mg} / \mathrm{kg})$ & $4902 d$ & $7580 b$ & $6459 c$ & $8875 a$ & $6928 b c$ & $9697 \mathrm{a}$ \\
\hline $\mathrm{Cu}(\mathrm{mg} / \mathrm{kg})$ & $21.52 \mathrm{a}$ & $21.66 \mathrm{a}$ & $15.36 \mathrm{c}$ & $17.67 b$ & $17.05 b$ & $16.62 b c$ \\
\hline $\mathrm{Mn}(\mathrm{mg} / \mathrm{kg})$ & $53.25 \mathrm{a}$ & $51.92 \mathrm{a}$ & $46.61 b$ & $45.51 b$ & $45.75 b$ & $44.16 b$ \\
\hline $\mathrm{Zn}(\mathrm{mg} / \mathrm{kg})$ & $56.92 \mathrm{a}$ & $40.66 b$ & $33.16 \mathrm{c}$ & $31.16 \mathrm{~cd}$ & $29.27 \mathrm{de}$ & $26.16 \mathrm{e}$ \\
\hline Moisture(\%) & $66.73 a$ & $60.99 \mathrm{~cd}$ & $67.86 a$ & $61.91 \mathrm{c}$ & $65.06 \mathrm{~b}$ & $60.23 d$ \\
\hline Density $\left(\mathrm{kg} / \mathrm{m}^{3}\right)$ & $676 c$ & $689 c$ & $856 a$ & $858 \mathrm{a}$ & $821 b$ & $823 b$ \\
\hline $\operatorname{Ash}(\%)$ & $22.26 f$ & $36.03 \mathrm{e}$ & $51.24 \mathrm{~d}$ & $59.34 b$ & $55.97 \mathrm{c}$ & $62.19 \mathrm{a}$ \\
\hline
\end{tabular}

${ }^{(1)}$ Refer to Table 1

${ }^{(2)}$ Different letters within the same row denote significant differences $(\mathrm{N}=18, \mathrm{P}=0.05)$

such as day temperatures and humidity during composting seasons 2013/14 and 2014/15, together with the combination of winery waste materials making up $\mathrm{T} 1$ probably resulted in increases in composting temperatures.

\section{Chemical parameters}

Chemical and physical parameters of winery solid waste composts as affected by composting and waste production seasons are indicated in Table 7. The wine filter waste compost parameters that were mostly affected by the 


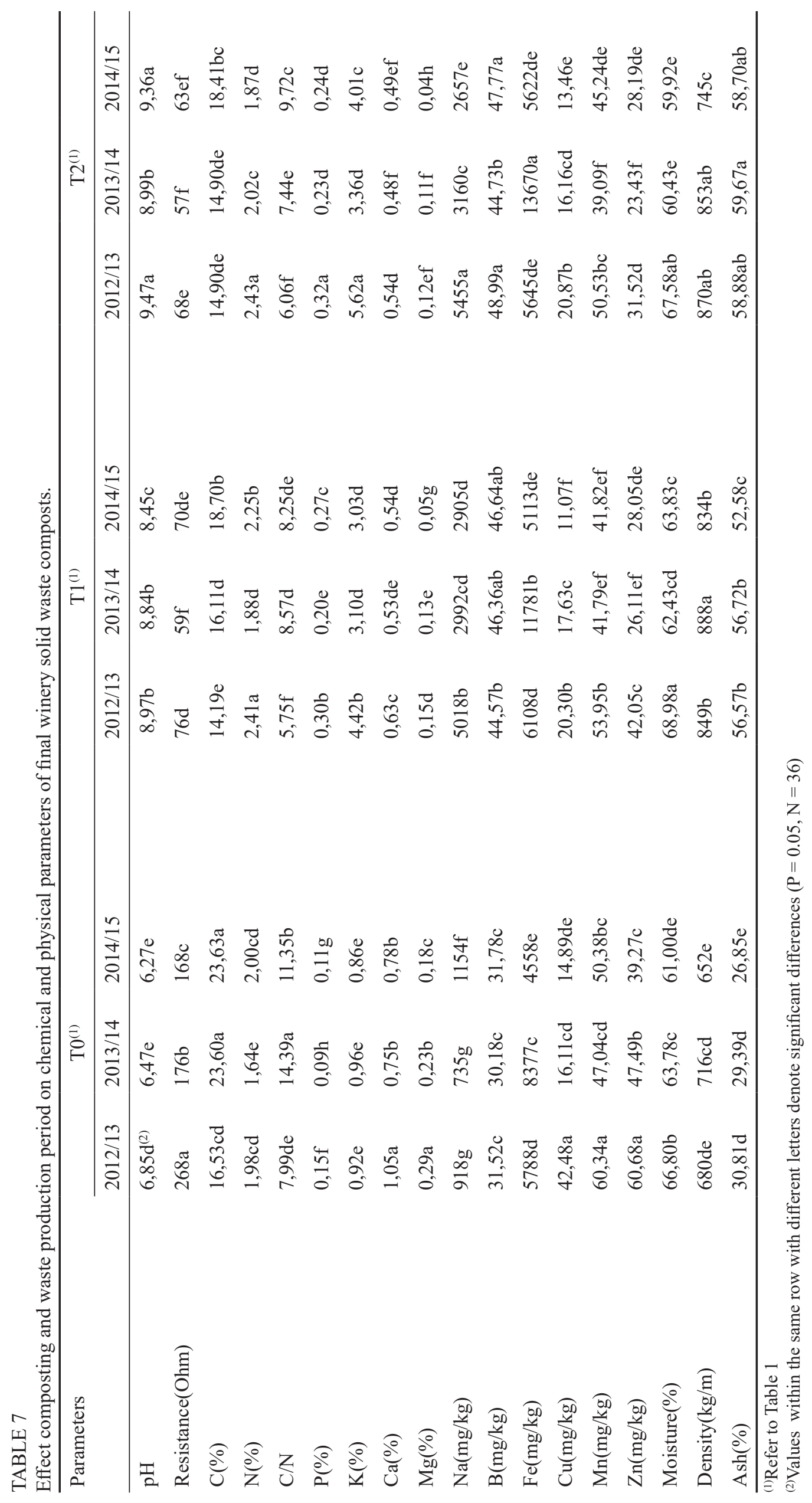


differences in composting seasons and waste production periods were $\mathrm{C}$ and $\mathrm{N}$ contents, $\mathrm{C} / \mathrm{N}$ ratios, $\mathrm{P}, \mathrm{K}$ and $\mathrm{Mg}$, $\mathrm{Na}, \mathrm{Cu}$ and $\mathrm{Mn}$ concentrations. T1 contained the lowest $\mathrm{C}$ contents in 2014/15 and highest in 2012/13. Both T1 and T2 contained the highest $\mathrm{N}$ contents during 2012/13, but for T1 the second highest were those of 2014/15 while for T2 those of 2013/14 (Table 6). T2 was found with the lowest C/N ratios during 2012/13, while the highest in 2014/15. T1 was found with the highest P levels in 2012/13 and the lowest in 2013/14.

T2 obtained the highest $\mathrm{K}$ levels in 2012/13 and the lowest in 2013/14. T1 contained Mg levels that were highest in 2012/13 and lowest in 2014/15 (Table 7). Sodium levels of T2 were the highest in 2012/13 and lowest in 2014/15. Copper levels of T1 were the highest in 2012/13 and lowest in 2014/15. Similarly, for T2, Cu levels were the highest in 2012/13 and lowest in 2014/15. T2 was found with the highest Mn levels in 2012/13 and lowest in 2013/14. Therefore, most of the chemical and physical parameters of both T1 and T2 were affected significantly by weather variations during composting seasons.

\section{DISCUSSIONS}

\section{Compost quality}

Over all three seasons of compost production, turning and lining of compost heaps significantly affected temperatures and some physical and chemical characteristics of the WFW composts. Turning of compost heaps significantly increased temperatures during composting. Also, turning of compost heaps significantly increased levels of $\mathrm{pH}, \mathrm{K}$, $\mathrm{P}, \mathrm{Fe}$, ash content, while decreasing resistance values, $\mathrm{C}$ and $\mathrm{N}$ contents, $\mathrm{C} / \mathrm{N}$ ratios, $\mathrm{Ca}$ and $\mathrm{Mg}$ contents, $\mathrm{Cu}$ and $\mathrm{B}$ concentrations, density values and moisture contents in both final WFW composts.

Furthermore, WFW composts can be characterised as follows: $\mathrm{pH}$ (9.8), resistance (58 Ohm), $\mathrm{C}: \mathrm{N}$ ratios (8:1) and total contents of $\mathrm{N}(2.44 \%), \mathrm{P}(0.34 \%), \mathrm{K}(\approx 6 \%), \mathrm{Na}(3665 \mathrm{mg} /$ $\mathrm{kg}), \mathrm{B}(54 \mathrm{mg} / \mathrm{kg})$ and $\mathrm{Fe}(5643 \mathrm{mg} / \mathrm{kg})$. The low resistance values were an indication of a presence of large amounts of salts, which was reflected by excessive Na levels. The low $\mathrm{C}$ : $\mathrm{N}$ ratio, indicated that WFW composts may be quick to release $\mathrm{N}$ upon application. Total $\mathrm{P}$ and $\mathrm{K}$ levels pointed to WFW composts being potential good sources of these nutrients, however, high total B levels were bothersome, and should be monitored closely upon application. Moreover, the WFW composts could be characterised as rich in Fe, but its availability to plants may be limited by alkaline conditions of the compost and competition for uptake by other micronutrients. In addition, some WFW compost parameters varied significantly with composting seasons, however, the two composts types were not always affected in the same manner. Nitrogen and $\mathrm{Cu}$ contents differed significantly with seasons for both WFW compost types. The high $\mathrm{pH}$ values suggest that when using wine filter wastes for composting, there is no need to use additives that are aimed at increasing the $\mathrm{pH}$. Turning of compost heaps increases temperatures, which is a positive factor during composting.

Composting surfaces should be lined and compost production practiced where leachate can be collected, as it alters the chemical composition of the soil. Furthermore, some compost parameters are likely to change from season to season as quantities of wine filter wastes generated seasonally vary. Total $\mathrm{K}$ levels that are greater than $0.5 \%$ as it is the case with both wine filter waste composts are considered high for composting (Raath \& Schutte, 2001). Nonetheless, only when the amount of compost that needs to be applied is determined, then the amount of $\mathrm{K}$ that needs to be applied will be known. It is possible that the wine filter waste compost could be beneficial for K deficient soils. Furthermore, wine filter waste composts, especially $\mathrm{T} 2$ contained higher $\mathrm{K}$ than $\mathrm{N}$ contents, which may be negative factor if not corrected during field application, as this may cause nutritional imbalance related problems with time (Raath \& Schutte, 2001). Sodium is generally an undesirable salt as it contributes to soil sodicity. Therefore, it can be assumed that the high $\mathrm{Na}$ concentrations of the wine filter waste composts may pose a huge problem and an environmental threat. In practice, though the amount of compost that is applied as well as the specific soil's exchangeable $\mathrm{Na}$ percentage determines how much $\mathrm{Na}$ can be tolerated by individual crops (Raath \& Schutte, 2001). Furthermore, when compost is used as an amendment, $\mathrm{Na}$ levels could be reduced through the dilution effect of mixing the compost with soil and leaching. Optimal $\mathrm{C}$ : $\mathrm{N}$ ratios for a finished or ripe compost have been reported to be those between 13:1 and 10:1 and the lower they are as in this study with the wine filter waste composts $(8: 1)$, the quicker the $\mathrm{N}$ mineral would be available during application. Levels of $\mathrm{N}$, $\mathrm{P}$ and $\mathrm{B}$ were within the ranges required in compost (Raath \& Fourie, 2006). However, a P supplement would be beneficial in practice and B levels would have to be monitored after application to avoid its accumulation.

\section{CONCLUSIONS}

The substrates and process parameters for effective composting using wine filter waste materials can now be defined following the method of production of the two wine filter waste composts produced in this study. Wine filter wastes together with grapevine pruning canes and berry skins, seeds and stalks could be used to make compost. A compost pile that has between $40 \%$ to $50 \%$ of wine filter wastes would result in successful composting and in a final compost product of acceptable chemical composition depending on the quality of the winery waste materials used. Composts made using wine filter wastes reached high temperatures $\left(50\right.$ to $67^{\circ} \mathrm{C}$ ) were alkaline (high $\mathrm{pH}$ ), potential good sources of $\mathrm{K}$ and $\mathrm{N}$. These however had low $\mathrm{C}: \mathrm{N}$ ratio, rich in $\mathrm{Fe}$, but have excessive $\mathrm{Na}$ and high $\mathrm{B}$ levels which should be monitored upon application. Turning of compost heaps increases temperatures due to aeration, which is a positive factor during composting. Furthermore, some compost parameters are likely to change from season to season as composting weather conditions, quantities and probably also chemical composition of wine filter wastes generated seasonally, vary. It is therefore important to have wine filter wastes analysed before composting. In addition, the use of more $\mathrm{C}$ and $\mathrm{N}$ rich material and inoculants could enhance the winery solid waste compost production process. 


\section{LITERATURE CITED}

Arvanitoyannis, I. S., Ladas, D., \& Mavromatis, A., 2006. Wine waste treatment methodology. International J. Food Sci. Technol. 41, 1117-1151.

Bertran, E., Sort, X., Soliva, M., \& Trillas, I., 2004. Composting winery waste: Sludges and grape stalks. Bioresource Technol. 95, 203-208.

Bonthuys, J., 2016. Recycling vs incineration. WineLand, 1- 2.

Masowa, M.M., Kutu, F.R., Babalola, O.O. \& Mulidzi, R., 2018. Physicochemical properties and phyto-toxicity assessment of co-composted winery solid wastes with and without effective microorganism inoculation. Res. Crops, 19, 549-559.

Masowa, M.M., Kutu, F.R., Shange, P.L., Mulidzi, R. \& Vanassche, F.M.G. 2015. The effect of winery solid waste compost application on maize growth, biomass yield, and nutrient content under greenhouse conditions. Arch. Agron. Soil Sci. 62, 1082-1094.

Mulidzi, A.R., 2021. Assessment \& monitoring the feasibility of winery solid waste management through composting. Scientia Agriculturae Bohemica (submitted for publication).

Mulidzi, A.R., 2001. Environmental Impact of Winery Effluent in the Western and Northern Cape Provinces. Thesis, University of Pretoria, Private Bag X20, Hatfield, 0028.
Mulidzi, A.R., Clarke, C.E. \& Myburgh, P.A., 2015. Effect of irrigation with diluted winery wastewater on cations $\& \mathrm{pH}$ in four differently textured soils. SA J. Enol. Vitic. 36, 402 - 412.

Mulidzi, A.R., Clarke, C.E. \& Myburgh, P.A., 2016. Effect of irrigation with diluted winery wastewater on Phosphorus in four differently textured soils. SA J. Enol. Vitic. 37, 79 - 84

Mulidzi, R., Augustine, P., Naude, M. \& Van Schoor, L., 2018. Guidelines for making compost using winery solid wastes. Wineland, 72-75.

Mtimkulu, Y., Meyer, A.H., Mulidzi, A.R., Shange, P.L \& Nchu, F., 2016. Assessing and monitoring the effects of filter material amendments on the bio physicochemical properties during composting of solid winery waste under open field and varying climatic conditions. Waste Management J. 59 , 59-69.

Raath, P. J. \& Fourie, J. C., 2006. Guidelines for making compost on a wine grape enterprise. WineLand, 96-97.

Raath, P. J. \& Schutte, C., 2001. Guidelines for monitoring soil fertility, plant nutrient status and compost quality in organic wine grape production systems. WineLand, 90-93.

Theron, C., 2013. Integrated Production of Wine (IPW) - the management of solid waste. WineLand, 7.

Zingelwa-Masekwana, N., 2012. Management of fining and filter waste in wineries. WineLand, $115-117$ 